Sofia, Bulgaria

\title{
MUSEUMS IN VILLAGES AS GUARDIANS OF FAMILY MEMORY AND CULTURAL HERITAGE
}

\begin{abstract}
Summary
The paper examines the activities of the museum in the village of Pavelsko - history, traditions and modern state. The museum is in the village's library and the exposition tells us about the life of the village from antiquity to the present day. This paper has been possible due to Project ДН15/4 of 11.12.2017 “Creating a Model for Preservation, Socialization and promotion of Orthodox Churches in Bulgaria" funded by the Bulgarian Science Fund.
\end{abstract}

Keywords: small villages, museum, library, cultural heritage

\section{INTRODUCTION}

The past and present gather in the museum collections of large and small towns and villages in Bulgaria. Guardians of cultural heritage, museums never cease to fascinate us with their interesting collections, gathered for years and with a lot of work. The museums in the small settlements are particularly impressive. Without being so rich in research, they are some kind of guardians of the memory of the generations that grew up in this region as museums leave lasting traces in the memory of the next generations.

The University of Library Studies and Information Technologies is working on a project of the Bulgarian Science Fund ДH15/4 of 11.12.2017

\footnotetext{
* m.nikolova@unibit.bg

** v.chantov@unibit.bg

*** University of Library Studies and Information Technologies, гр. София, п.к. 1784 бул. “Цариградско шосе" № 119
} 
"Creating a Model for Preservation, Socialization and promotion of Orthodox Churches in Bulgaria". The work of the project includes research in different areas of the country with a great deal of attention being paid to the preservation of temples in small settlements where they are part of the cultural heritage.

The Museum with "Aleko Konstantinov" Chitalishte in the village of Pavelsko is the subject of the study presented in this article. The patron of the family memory, the museum in this dynamic world of technology and forgotten human values is the guardian of the local memory, the rich past and the colorful history of the village and its inhabitants. Learning something new about their family, one goes to the future with the self-esteem of a descendant of a people with a glorious past and rich culture. The article also outlines the importance and role of the museum in preserving the cultural heritage of the region.

The village of Pavelsko is one of the oldest villages in Dolen Rupchos occupying part of the northern slopes of the Central Rhodopes. In ancient times, the area was inhabited by Thracians, and later by the Romans, who left many traces in the village. In the area, there are also many monasteries and localities connected with monasteries and saints from the Christian calendar, which speaks of a very strong and old presence of Christianity. Archaeological finds found in the area of the village are proof that there have been settlements there since antiquity. When creating the historical map of Bulgaria for the period before the $5^{\text {th }}$ Century of the new era, only Pavelsko and Gela are mentioned in the villages. From Roman time onwards through the village, there have been road arteries from Plovdiv to Aegean Thrace. The first information about the present settlement dates from 1515 when it appeared in the Ottoman register of settlements in Ruptsa Nakhiya as Pavlikko and numbered 29 households. Nine years later - in 1524 - they were 38.

\section{THE MUSEUM COLLECTION}

The creation, organization and maintenance of museum collections at the Chitalishte /Cultural Community Centres/ in Bulgaria is of particular importance both for preserving and protecting the historical values but 
also for their popularization among the younger generation. The contemporary situation in the country requires us to seek opportunities through the help of projects that stimulate these activities to support the work in the museums of the local lands. Thanks to the project "Research, Digitization and Systematisation of Exhibits and Archival Units in the Chitalishte Local Museum in Pavelsko, Smolyan", we have the opportunity to trace the contemporary state of the museum and make the relevant conclusions for its role as guardian of the family memory.

The museum collection in the village of Pavelsko was founded in 1934 by the local resident Stefan Vyagov - a man with diverse interests and a teacher in the village, as part of the Aleko Konstantinov community culture center with a variety of exhibits presenting the history of the village. These are household items, books and documents that are kept in the archives of the museum collection. Stefan Vyagov decided to open a museum at the Chitalishte in order to preserve the cultural memory of the village. He collected books and other historical values by placing them in one of the rooms of the school. The collection is mentioned as the first of its kind in the region in all the books about the village. The museum collection at the outset included archaeological finds, valuable books, and family photos from different village clans that he personally sought. In 1971 the Chitalishte Board of Trustees together with prominent public figures - residents of Pavelsko - decided to extend the collection to the Chitalishte.

The museum is small, but it offers visitors a lot of diverse exhibits, showing us the story not only through the sight of the lens but also through the exhibits of everyday life. Here we also find the history of the village through the books and documents which are kept in the archives of the museum collection at the Chitalishte.

The museum fund can be viewed as follows:

1. Objects (of the households and costumes of the Bulgarians) from the central Rhodope Mountains from the end of the 19th and the beginning of the 20th century;

2. Archives of documents;

3. An archive of photos related to important events, people and places of historical importance;

4. Educational literature from Stefan Vyagov's personal archive;

5. A collection of stamps and medals. 
1. Many archaeological finds speak about the life of the population of the village of Pavelsko, evidence of the lasting presence of the Thracians and the Slavic tribes. Excavations were made in the region in the Chernaki area, where among the 12 graves were found objects such as: glass vessels, glasses, buckles and coins from the late Roman epoch. In the mound St. Nedelya, 2 skeletons with heads turned to the east, bronze fibula, rings, earrings, ornaments for the neck, and a skeleton with a head turned to the east and a bronze fibula were found in the mound in the Ravnishta area. In the "Tuzlata" mound, near the "Cherkva" area were found iron peaks of arrows, an iron sword and a fibula. In 1933, in the place of Dukinka were found graves with ornaments, a cross, 3 bronze fibulae and an iron pick of a spear. Fibulae and bronze pins were found at the mound at Pravtsy and in one of the graves in the Charnaki area there were 42 coins from the time of Emperor Theodosius II on the chest of the skeleton. In the museum are preserved plates of ancient origin, which until now remains unknown and their inscriptions are still unreadable. There are many documents and written records of archaeological finds and preserved values from the village of Pavelsko, a testimony of the lasting presence of the Thracians and Slavic tribes.The museum exhibition presents traditional objects from theeveryday life of the local population: wooden spoon and fork, a grater, prosfornik (a wooden cross that has been placed on the bread before it is baked), frames for ornaments, a wedding vase, brandy cup, a hot pot gripper, a blade for flipping pancakes, a smoothing grater, an axe for chopping the hay, a hammer with which the hair was scraped, a mortar and a milling machine. The museum has sheltered rough semiprecious stones, as well as shields, crossbow parts, and a 20thcentury cult-like vessel found in the village. There is an ink cartridge belonging to one of the founders - Stefan Vagov - with two pens and two bottles of ink.

2. Documents on the liberation movements in the area of Dolny Rupchos including the villages Pavelsko, Hvoyna and Orehovo, can also be seen in the village museum. Among the valuable 
documents in the museum collection are ballots, books, tax notebooks with the face of Alexander Stamboliiski and other securities.

3. In 1971, upon the decision of the Chitalishte Board of Trustees, the museum exposition in the chitalishte in the village of Pavelsko expanded with a rich collection of archival documents and a variety of pictures. In the spacious room, where the museum is at present, pictures of significant village events were exhibited, such as the opening of the first workshop for leather products of Chaika factory (branch of the Chaika factory in Plovdiv). Later a new building of the workshop was erected. A great event for the residents of the village was the opening of "Pashalitsa Hut" - a tourist hut among one of the most beautiful places in the Rhodope Mountains. Pictures from the event can be seen in the museum. There are also photographs in the museum at the Chitalishte: the participants of the First World War, the Seventh Company, the $21^{\text {st }}$ Infantry Regiment of the Middle Ages; of Nikola Rinevski - a participant in the Vladaya Uprising; photos of the monuments in the village, photos of Dimitar Belev - MP in the Third Grand National Assembly, Angel Chichkov, Todor Staykov, etc., a series of photographs selected by Stefan Vaygov represent the Rhodope wedding. The other co-founder of the museum Yordan Semerdjiev has helped to make a new part of the museum, which includes drawings illustrating the history of the village, the mounds, the participants in the wars, the churches and the chapels, the development of education and culture in the village and sporting events. There are many photos of participants in the Serbian-Bulgarian War, school testimonies, Thracian mounds from the district of Chiperki.

4. Exhibits in the museum tell the history of education in the village of Pavelsko. These are old books and tablets that the students have written on in the past. There is a preserved old encyclopaedia in the museum which presents the history of the village of Pavelsko and the burning of the village during the Ottoman Turks invasion, which is devoted to the Russo-Turkish liberation war. The liberation of Pavelsko on January $15^{\text {th }}$ by General Charevin, commander 
of the Caucasian Brigade, is presented on an information board. The history of the local church, one of the first two churches built in the Rhodopes in 1834, is the most significant one in the museum's exhibition. The church was built on the initiative of local leaders, some of whom paid with their lives for that. The original name of the church was St. "Spas", but then changed to "Christ's Ascension". Experts believe that part of the iconostasis was painted by Zachary Zograph.

5. The Chitalishte in the village of Pavelsko has always been a center of active local cultural life. There was a self-contained dramatic ensemble, folk songs and dances ensemble and a library. Numerous are the awards, medals and prizes for the chitalishte of the village of Pavelsko kept in the museum. The artistic ensemble founded in 1950 with a staff of 120 people won the first place in the national competition in Sofia the following year. The 30-people orchestra leader was Apostol Kisyov, and the ensemble was led by Golemanski - who won many medals and awards. One of the most valuable exhibits in the museum is the seal of the commander of the $61^{\text {st }}$ Don Kazak Horse Regiment preserved in the village of Pavelsko from the liberation war of 1878. Among the exhibits are the medals of Stefan Vyagov $2^{\text {nd }}$ degree, a passport, manuscripts, certificates and diplomas. You can also see valuable seals and certificates of the Chitalishte won in prestigious competitions in Koprivshtitsa, Rozhen and others, the oldest preserved diploma in the museum is from the town of Smolyan - 1953.

As is evident from the exposition, the Chitalishte Museum in the village of Pavelsko in a rather naive and even unscientific way presents the history, the village everyday life, as well as the chronicle of the important local events. Still, we will repeat that the museum is hardly in line with the contemporary scientific requirements for organizing an active local Museum. But in this case, which is not the only one in the country, it is important that the inhabitants of the small settlements make the most of their efforts, they strive to succeed in preserving and passing on to the next generations impor- 
tant cultural monuments of the village. Thus, they provide an example of how through careful preservation and protection of material cultural heritage in a museum exposition such as that in the village of Pavelsko, one can trace the historical development and show the rich past of the smaller settlements in the country. Thus, museums in such settlements become the most reliable guardian of the cultural and historical heritage.

\section{Sources:}

Калинов, Хр. Д. Миналото на село Павелско (историко-географски очерк). (1967) 2014.Община Чепеларе. Кметство с. Павелско.

Семерджиев, Й. Будител на народната свяст. 135 години читалище „Алеко Константинов", с. Павелско. Пловдив: КСИ ЕООД, 2015.

Николова, М. Николова, В. Читалищният музей в с. Павелско - пазител на културноисторическото наследство. София: За буквите - О писменехь, 2015.

Николова, М. Николова, В., Минчева, К. Музеят и музейният фонд към читалище „Алеко Константинов“ в с. Павелско - настоящо състояние и бъдещо развитие. XIII национална научна конференция с международно участие, София, 1 ноември 2015 г. София: За буквите - О писменехь, 2016.

\section{Марија Николова \\ Веселин Чантов}

\section{МУЗЕЈИ У СЕЛИМА КАО ЧУВАРИ ПОРОДИЧНИХ СЕЋАҢА И КУЛТУРНОГ НАСЛЕЪА}

\section{Сажетак}

Рад истражује активности музеја у селу Павелско - историју, традицију и модерну државу. Музеј је у библиотеци села и изложба нам говори о животу села од антике до данашњег дана.

Кључне речи: мала села, музеј, библиотека, културна баштина 